\title{
In Vitro Study on Apoptosis Induced by Strontium-89 in Human Breast Carcinoma Cell Line
}

\author{
Cheng Wang, ${ }^{1,2}$ Jing Wang, ${ }^{1}$ Han Jiang, ${ }^{1}$ Min Zhu, ${ }^{2}$ Baoguo Chen, ${ }^{2}$ and Weiguang Bao ${ }^{2}$ \\ ${ }^{1}$ Department of Nuclear Medicine, Second Affiliated Hospital of Zhejiang University School of Medicine, \\ Hangzhou, Zhejiang 310009, China \\ ${ }^{2}$ Department of Nuclear Medicine, Taizhou Hospital, Taizhou, Zhejiang 317000, China \\ Correspondence should be addressed to Jing Wang, wangjingisme@gmail.com
}

Received 30 December 2010; Revised 24 March 2011; Accepted 25 March 2011

Academic Editor: Zhen Cheng

Copyright () 2011 Cheng Wang et al. This is an open access article distributed under the Creative Commons Attribution License, which permits unrestricted use, distribution, and reproduction in any medium, provided the original work is properly cited.

\begin{abstract}
Many radiopharmaceuticals used for medical diagnosis and therapy are beta emitters; however, the mechanism of the cell death caused by beta-irradiation is not well understood. The objective of this study was to investigate the apoptosis of human breast carcinoma MCF-7 cell lines induced by Strontium-89 $\left({ }^{89} \mathrm{Sr}\right)$ and its regulation and control mechanism. High-metastatic Breast Carcinoma MCF-7 cells were cultured in vitro using ${ }^{89} \mathrm{Sr}$ with different radioactive concentration. The inhibition rate of cell proliferation was measured by MTT color matching method. The cell cycle retardation, apoptosis conditions, mitochondrion transmembrane potential difference and Fas expression were tested and analyzed. The genes P53 and bcl-2 expressions was also analyzed using immunity histochemical analysis. After being induced by ${ }^{89} \mathrm{Sr}$ with various of radioactive concentration, it was found that the inhibition of cell proliferation of MCF-7 cells was obviously, the retardation of cell cycle occurred mainly in G2-M. It was also found that the obvious apoptosis occurred after being induced by ${ }^{89} \mathrm{Sr}$, the highest apoptosis rate reached $46.28 \%$. The expressions of Fas acceptor and P53 gene increased, while bcl-2 gene expression decreasesd. These findings demonstrate that in the ranges of a certain radioactive concentration, the inhibition rate of MCF-7 cell proliferation and retardation of cell cycle had positive correlation with the concentration of ${ }^{89} \mathrm{Sr}$. And the mitochondrion transmembrane potential decrease would induce the apoptosis of MCF-7 cell notably, which were controlled by P53 and bcl-2 genes, involved with the Fas acceptor.
\end{abstract}

\section{Introduction}

Cancer is a major public health problem in the United States and other countries. Currently, one in four deaths in the United States is due to cancer [1]. Among the major therapy approaches, ionizing radiation is used as a widespread therapeutic modality for cancer treatment. Currently, one of the challenges in radiobiology and oncology is to understand how the cells respond to oxidative stress resulting from exposure to radiation, whether they will die by an apoptotic process or will survive and proliferate. From the point of view of neontology, DNA and cell membrane are the targets of ionization radiation therapy, which gives rise to a series of biochemical and physiological changes of cells, and then induce the inhibition of cell proliferation and retardation of cell cycle, even apoptosis and necrosis. The therapeutic change has relation to the sensitivity, time phase of cell cycle, absorbed radiation dose, and the type of ray [2-4].
It is well known that cell exposure to radiation results in direct and indirect DNA damage, and the extent of damage will depend on the type of radiation and the dose applied, as well as other factors. The higher the ionization density, that is, the higher the radiation linear energy transfer (LET), the greater the complexity of the lesions, and, therefore, repair of the induced lesions is more difficult. When activated by gamma irradiation, p53 induce apoptosis pathways by its positive transcriptional activity on proapoptotic molecules [5]. DNA damage and p53 activation may be initial events in gamma-irradiation-induced apoptosis [5]. In addition, mitochondria-directed apoptotic stimuli induce a variety of mitochondrial changes, including production of oxygen radicals and the opening of membrane pores. This leads to the release of apoptogenic factors such as cytochrome c, apoptosis-inducing factor (AIF). The status of cell proliferation and cell cycle are also thought to be important factors to radiation-induced apoptosis [6]. Radiation-induced cell 
cycle arrest at the G1 and G2 restriction points allows cells to repair DNA damage before cells proceed with DNA synthesis and cell division. It is known that irradiated non-smallcell lung cancer (NSCLC) cell lines with wild-type p53 pass beyond the G1 and G2 blocks with delayed and markedly lower probability than cell lines with inactive p53. As a result, the fraction of late post-G2 apoptosis, induced in NSCLC cell lines with intact p53, was lower than in cell lines with functionally inactive p53 [7].

Studying the effects of $\beta$ radiation at the cellular level is of particular interest for direct application in nuclear medicine. Many radiopharmaceuticals used for diagnosis and therapy are $\beta$ emitters (e.g., ${ }^{153}$ Sm-EDTMP, $\mathrm{Na}^{131} \mathrm{I},{ }^{186}$ Re-HEDP, and ${ }^{89} \mathrm{SrCl}$ ), which showed promising therapeutic results. However, the mechanism by which cell death is caused by $\beta$ irradiation is not well understood. ${ }^{89} \mathrm{Sr}$ therapy has the best effect on breast carcinoma and prostate carcinoma; breast carcinoma MCF-7 is a high metastatic cell type, so we choose MCF-7 as the model. In this study, we investigated the mechanism for apoptosis in response to ${ }^{89} \mathrm{Sr}$, one of the significant and effective $\beta$ radiation emitting therapeutic radioisotopes, in breast carcinoma MCF-7 cells.

\section{Materials and Methods}

2.1. Cell Culture. Human breast carcinoma MCF-7 cells were grown in RPMI 1640, containing $10 \%$ fetal calf serum. Cells were incubated in a $37^{\circ} \mathrm{C}$ incubator with $95 \%$ air, $5 \%$ $\mathrm{CO}_{2}$, and $100 \%$ humidity. Fresh medium was supplemented every 2 days. Passaging was carried out every 3-4 days and consisted of a gentle mechanical dissociation using a polished Pasteur pipette. The cells in the logarithmic growth phase are adopted in all the experiments.

2.2. Inhibition of Cell Proliferation by ${ }^{89} \mathrm{Sr}$. The equilibrium dose constant for ${ }^{89} \mathrm{Sr}$ is $9.32 \times 10^{-14} \mathrm{~Gy} \mathrm{~kg} \mathrm{~Bq}^{-1} \mathrm{~s}^{-1}$

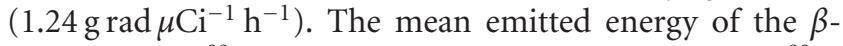
particle from ${ }^{89} \mathrm{Sr}$ is $0.583 \mathrm{MeV}\left(E_{\max }=1.492 \mathrm{MeV}\right) .{ }^{89} \mathrm{Sr}$ solution was purchased from Shanghai Anshen Kexing Corporation as a kind of leuco transparent liquid, $\mathrm{pH}$ value = 8.0 , radiochemical purity $>98 \%$, radioactive specific activity $=3.7 \times 10^{7} \mathrm{~Bq} / \mathrm{mL}$. MCF-7 cell solution was adjusted as $1 \times 10^{5} / \mathrm{mL}$. Every orifice inoculated $100 \mu \mathrm{L}$ MCF-7 cell solution on the 96-orifice cell culture plate, applied with ${ }^{89} \mathrm{Sr}$ solution in different concentrations of $37 \mathrm{~Bq} / \mathrm{mL}$, $74 \mathrm{~Bq} / \mathrm{mL}, 148 \mathrm{~Bq} / \mathrm{mL}, 296 \mathrm{~Bq} / \mathrm{mL}, 592 \mathrm{~Bq} / \mathrm{mL}, 1184 \mathrm{~Bq} / \mathrm{mL}$, $2368 \mathrm{~Bq} / \mathrm{mL}$, and $4736 \mathrm{~Bq} / \mathrm{mL}$. Every group has 3 duplicate orifices as control orifice of normal cells. MCF-7 cells were incubated with ${ }^{89} \mathrm{Sr}$ at $37^{\circ} \mathrm{C}$ with $95 \%$ air, $5 \% \mathrm{CO}_{2}$, and $100 \%$ humidity for $24 \mathrm{~h}$. At the time of 4 hours before the culturing finished, $10 \mu \mathrm{L}$ MTT $(5 \mathrm{mg} / \mathrm{mL}$ ) was added to every orifice, continued to incubate 4 hours, and then carried through level centrifugal cleaning culturing plate. $150 \mu \mathrm{L}$ DMSO was added to each orifice and fully blended, and then absorbance was determined using a spectrophotometer at $570 \mathrm{~nm}$ absorbance.

2.3. Determination of Cell Cycle Phase. Cells at different stages of the cell cycle can be distinguished by their
DNA content. Experimentally, cellular DNA content can be determined by incubation with a fluorescent dye (propidium iodide) that binds to DNA, followed by analysis in fluorescence-activated cell sorter (FACS). In this study, collected MCF-7 cells were added 70\% ethanol, kept steady for 24 hours at $-20^{\circ} \mathrm{C}$, and washed twice by PBS, adjusted cells solution to be $1 \times 10^{6} / \mathrm{mL}$. Then $100 \mu \mathrm{L}$ of cell suspension was added to test tube with $200 \mu \mathrm{L} \mathrm{PI}$, reacted at $4^{\circ} \mathrm{C}$, no light, for 30 minutes, then tested by using a flow cytometer (FACScan, Becton Dickinson) and analyzed the results. The Cycletest Plus DNA Reagent Kit (BD Corporation) was used in detecting the distribution of cells within the different phases of cell cycle.

2.4. Measurement of Cell Apoptosis. $1 \times 10^{5} / \mathrm{mL} \mathrm{MCF-7} \mathrm{cells}$ were moved to 6 orifices, then ${ }^{89} \mathrm{Sr}$ solution in different concentrations of $37 \mathrm{~Bq} / \mathrm{mL}, 74 \mathrm{~Bq} / \mathrm{mL}, 148 \mathrm{~Bq} / \mathrm{mL}, 296 \mathrm{~Bq} / \mathrm{mL}$, $592 \mathrm{~Bq} / \mathrm{mL}, 1184 \mathrm{~Bq} / \mathrm{mL}, 2368 \mathrm{~Bq} / \mathrm{mL}, 4736 \mathrm{~Bq} / \mathrm{mL}, 185 \mathrm{kBq} /$ $\mathrm{mL}, 370 \mathrm{kBq} / \mathrm{mL}, 740 \mathrm{kBq} / \mathrm{mL}, 1480 \mathrm{kBq} / \mathrm{mL}, 2960 \mathrm{kBq} / \mathrm{mL}$, $3330 \mathrm{kBq} / \mathrm{mL}, 6660 \mathrm{kBq} / \mathrm{mL}$, and $13320 \mathrm{kBq} / \mathrm{mL}$, respectively, and incubated at $37^{\circ} \mathrm{C}, 5 \% \mathrm{CO}_{2}$ for 24 hours. After twice centrifugal washing of the cells with precooling PBS, the cells were resuspended in $100 \mu \mathrm{L}$ of PBS and then were added $5 \mu \mathrm{L}$ AnnexinV ${ }^{\text {FITC }}$ (Bender MedSystems Corporation) solution and fully blended. Then the cells were tested using flow cytometer soon after 15 -minute reaction at $4^{\circ} \mathrm{C}$ without light and adding $10 \mu \mathrm{L}$ PI. This measurement was repeated for the $3330 \mathrm{kBq} / \mathrm{mL}$ group at time points of $36 \mathrm{~h}$, $48 \mathrm{~h}$, and $72 \mathrm{~h}$.

2.5. Measurement of Mitochondrial Membrane Potential. Mitochondrial membrane potential, $\Delta \Psi m$, is an important parameter of mitochondrial function used as an indicator of cell health. To evaluate $\Delta \Psi m$, MCF-7 cells were incubated with ${ }^{89} \mathrm{Sr}$ with the above concentration for 24 hours, then treated with Rh123C and followed by analysis on a flow cytometer (FACScan, Becton Dickinson).

2.6. Fas Detection. The cell surface Fas (CD95/APO-1) is a $45 \mathrm{kD}$ type I membrane protein, and Fas ligand (FasL) is a 37 to $40 \mathrm{kD}$ type II membrane protein that belongs to the tumor necrosis factor (TNF) receptor and ligand families [8]. Activation of Fas by crosslinking with agonistic antibodies or by binding with FasL resulted in apoptotic cell death in susceptible cells [9]. The three MCF-7 cell groups were incubated separately with $3330 \mathrm{kBq} / \mathrm{mL}, 6660 \mathrm{kBq} / \mathrm{mL}$, and $13320 \mathrm{kBq} / \mathrm{mL}$ for 24 hours, then collected cells and suspended in PBS and adjusted cells concentration as $1 \times$ $10^{6} / \mathrm{mL}$. The $100 \mu \mathrm{L}$ of cells suspension was incubated in two tubes, one with $20 \mu \mathrm{L}$ mouse IgG fluorescein isothiocyanate (FITC) used as homotype reference, and another tube with $20 \mu \mathrm{L}$ Fas FITC was incubated at $4^{\circ} \mathrm{C}$ without light for 15 minutes. The cells were analyzed for surface Fas expression by flow cytometer.

2.7. DNA Gel Electrophoresis. DNA damage and cell apoptosis were detected by DNA gel electrophoresis. DNA of MCF-7 cells were extracted after being induced by ${ }^{89} \mathrm{Sr}$ at different 
concentrations as shown previously for 24 hours. After air drying, cells were conserved in the TE buffer solution. DNA sample was taken out and electrophoresed in $1.2 \%$ agarose gel with $100 \mathrm{~V}$ for 30 to 60 minutes and detected by pigment EB staining. The DNA samples were investigated by ultraviolet spectrometry and then imaged.

2.8. Immunohistochemical Analysis. The cell coverslips were incubated with $100 \mathrm{uL}$ rabbit anti-Bcl-2 and rabbit anti-P53 over night at $4^{\circ} \mathrm{C}$. After rinsing with tris-buffered saline (TBS) for five times, $5 \mathrm{~min}$ each rinse, the coverslips were incubated in rabbit antimouse secondary antibodies for $30 \mathrm{~min}$ at $37^{\circ} \mathrm{C}$. The coverslips were subsequently rinsed with TBS for five times, $5 \mathrm{~min}$ each rinse and then added $100 \mathrm{uL}$ DAB solution to each coverslip and incubated coverslips for 1 minute at room temperature.

2.9. Estimation of the Cell Integral Absorbed Dose by ${ }^{89} \mathrm{Sr}$. The estimation of the cell integral absorbed dose by ${ }^{89} \mathrm{Sr}$ was calculated based on the following formula $[4]: D=A E / m$, where $D$ is absorbed dose, $A$ the radioactive activity of ${ }^{89} \mathrm{Sr}$ internal radiation (unit: $\mathrm{kBq}$ ), $E$ the average energy of ${ }^{89} \mathrm{Sr}$ ray, and $m$ the mass of the irradiated cell.

2.10. Statistical Analysis. All data are calculated as percentage. $\mathrm{X}^{2}$ verification is adopted between groups.

\section{Results}

3.1. MCF-7 Cell Integral Absorbed Dose by ${ }^{89}$ Sr Internal Radiation. After being induced by ${ }^{89} \mathrm{Sr}$ with various radioactive concentrations $(37 \mathrm{~Bq} / \mathrm{mL}, 74 \mathrm{~Bq} / \mathrm{mL}, 148 \mathrm{~Bq} / \mathrm{mL}, 296 \mathrm{~Bq} /$ $\mathrm{mL}, 592 \mathrm{~Bq} / \mathrm{mL}, 1184 \mathrm{~Bq} / \mathrm{mL}, 2368 \mathrm{~Bq} / \mathrm{mL}, 4736 \mathrm{~Bq} / \mathrm{mL}, 185$ $\mathrm{kBq} / \mathrm{mL}, 370 \mathrm{kBq} / \mathrm{mL}, 740 \mathrm{kBq} / \mathrm{mL}, 1480 \mathrm{kBq} / \mathrm{mL}, 2960 \mathrm{kBq} /$ $\mathrm{mL}, 3330 \mathrm{kBq} / \mathrm{mL}, 6660 \mathrm{kBq} / \mathrm{mL}$, and $13320 \mathrm{kBq} / \mathrm{mL})$, the accumulative absorbed doses are measured as $0.025 \mathrm{mGy}$, $0.05 \mathrm{mGy}, 0.1 \mathrm{mGy}, 0.2 \mathrm{mGy}, 0.4 \mathrm{mGy}, 0.8 \mathrm{mGy}, 1.6 \mathrm{mGy}$, $3.2 \mathrm{mGy}, 0.125 \mathrm{~Gy}, 0.25 \mathrm{~Gy}, 0.5 \mathrm{~Gy}, 1 \mathrm{~Gy}, 2 \mathrm{~Gy}, 2.25 \mathrm{~Gy}, 4.5 \mathrm{~Gy}$, and $9 \mathrm{~Gy}$, respectively. If induced by ${ }^{89} \mathrm{Sr}$ with the radioactive concentration of $3330 \mathrm{kBq} / \mathrm{mL}$ for 36 hours, 48 hours, and 72 hours, the accumulative absorbed doses are $3.38 \mathrm{~Gy}, 4.5 \mathrm{~Gy}$, and $6.76 \mathrm{~Gy}$, respectively.

3.2. MCF-7 Cellular Morphological Change and Cell Proliferation Inhibition. After being induced by ${ }^{89} \mathrm{Sr}$ with various radioactive concentrations $(74 \mathrm{~Bq} / \mathrm{mL}, 148 \mathrm{~Bq} / \mathrm{mL}, 296 \mathrm{~Bq} /$ $\mathrm{mL}, 592 \mathrm{~Bq} / \mathrm{mL}, 1184 \mathrm{~Bq} / \mathrm{mL}, 2368 \mathrm{~Bq} / \mathrm{mL}$, and $4736 \mathrm{~Bq} / \mathrm{mL}$ ) and cultured for 24 hours, the numbers of MCF-7 cells obviously decreased and cellular morphological change occurred obviously, the outline shrank, and the function of adhering to the cell wall layer was found to be obviously weakened compared with the control group (Figure 1).

No obvious inhibition was found at $37 \mathrm{~Bq} / \mathrm{mL}$. With the increase of the concentration (exceeding $74 \mathrm{~Bq} / \mathrm{mL}$ ), the proliferation inhibition rate obviously rose, showed a positive correlation with the concentration (Figure $2, P<.05$ ).

3.3. MCF-7 Cell Cycle Retardation. After being induced by ${ }^{89} \mathrm{Sr}$ with various radioactive concentrations $(185 \mathrm{kBq} / \mathrm{mL}$,

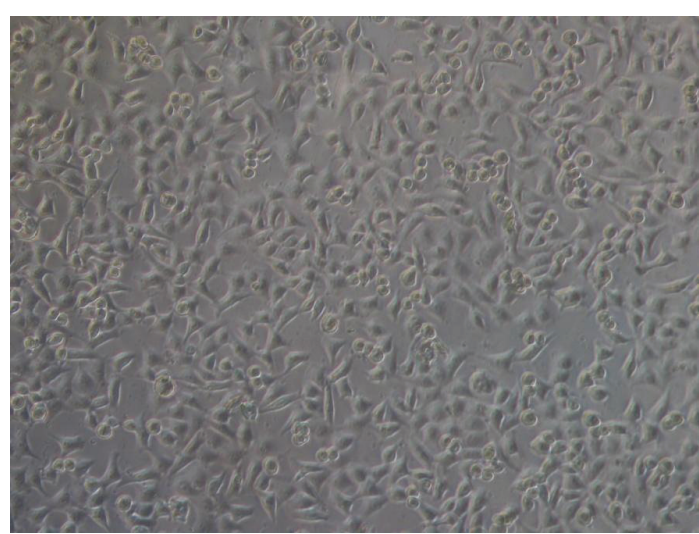

(a)

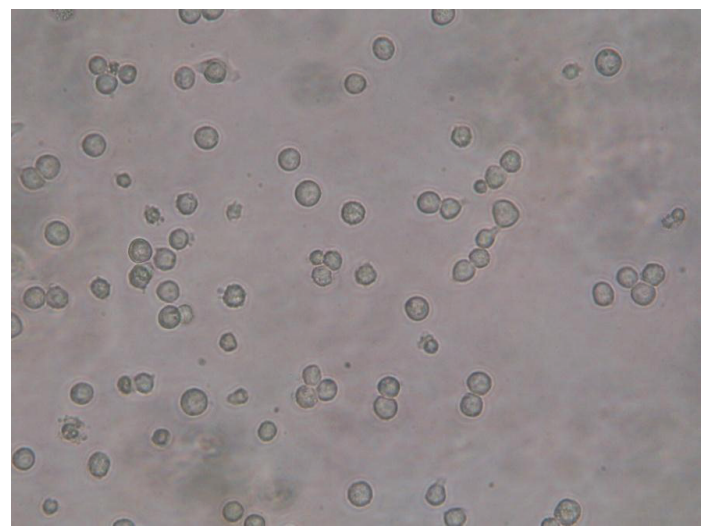

(b)

FIGURE 1: Digital photo before (a) and after (b) being induced by ${ }^{89} \mathrm{Sr}(3330 \mathrm{kBq} / \mathrm{mL})$ (microscopically).

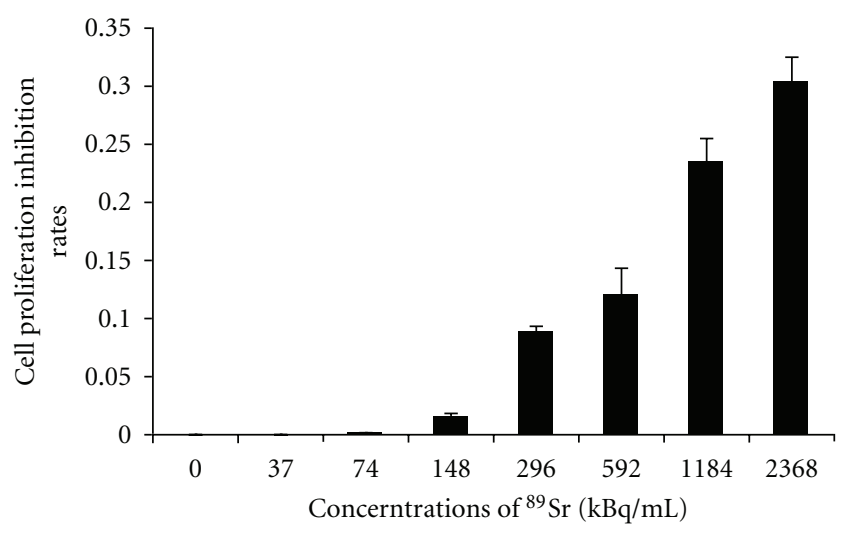

Figure 2: MCF-7 cell proliferation inhibition rate due to being induced by ${ }^{89} \mathrm{Sr}$ of various concentrations.

$370 \mathrm{kBq} / \mathrm{mL}, 740 \mathrm{kBq} / \mathrm{mL}, 1480 \mathrm{kBq} / \mathrm{mL}, 2960 \mathrm{kBq} / \mathrm{mL}, 3330$ $\mathrm{kBq} / \mathrm{mL}, 6660 \mathrm{kBq} / \mathrm{mL}$, and $13320 \mathrm{kBq} / \mathrm{mL}$ ) and cultured for 24 hours, the retardation appeared obvious. The retardation became significant when the concentration increased. The retardation was mainly found in the cycle G2-M at the concentration less than $6660 \mathrm{kBq} / \mathrm{mL}$, reached the 


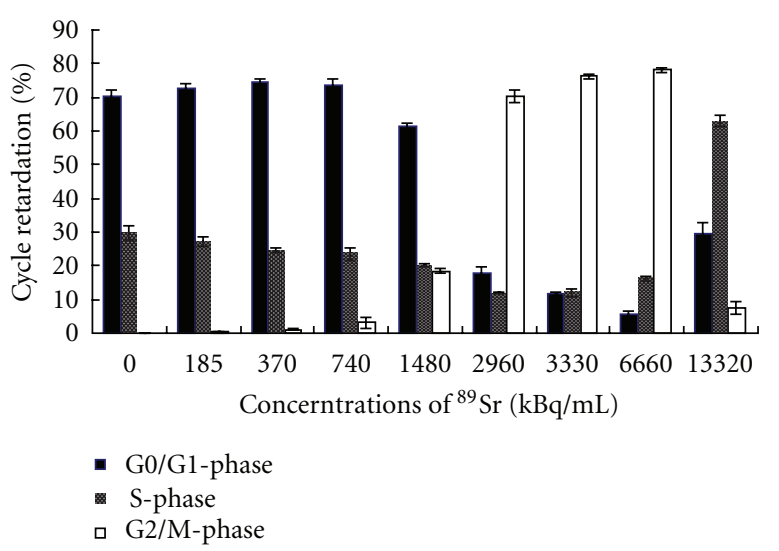

Figure 3: MCF-7 cell cycle retardation due to being induced by ${ }^{89} \mathrm{Sr}$ of various radioactive concentrations.

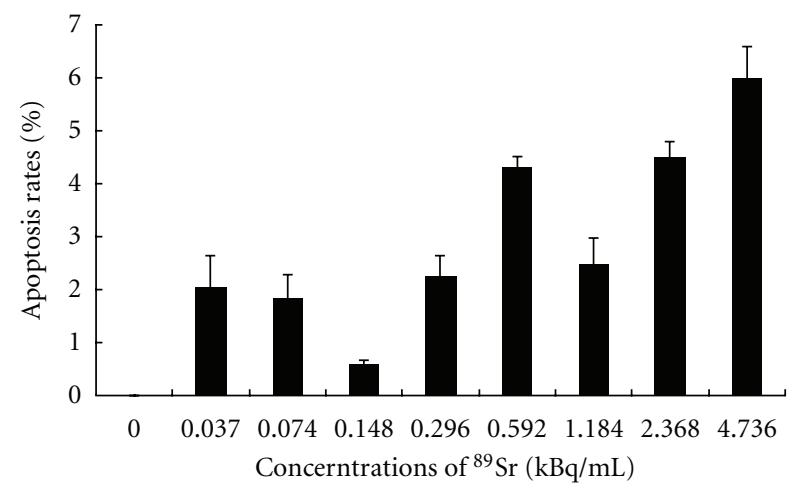

Figure 4: Percentage of MCF-7 cell apoptosis due to being induced by ${ }^{89} \mathrm{Sr}$ of various radioactive concentrations.

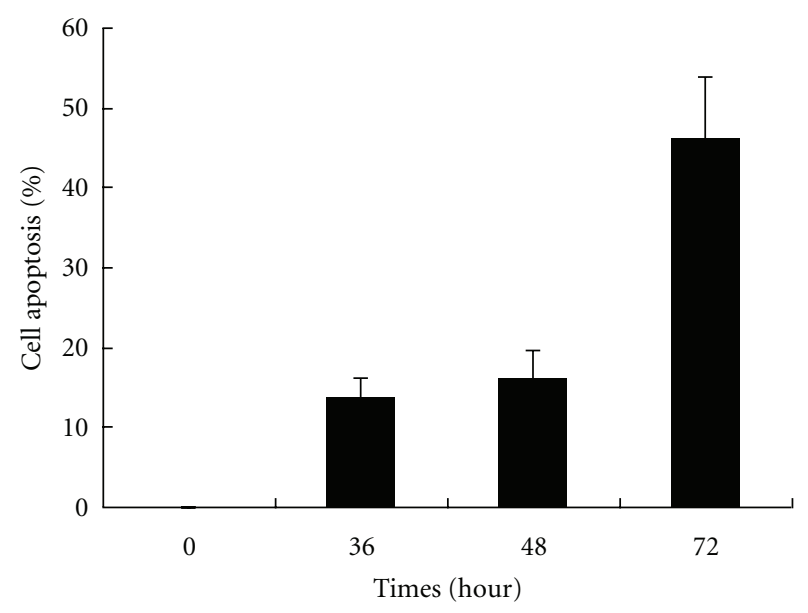

FIgURE 5: Cell apoptosis of 4 groups of the experimental group $3330 \mathrm{kBq} / \mathrm{mL}$.

peak at $78.09 \%$. When the concentration was more than $13320 \mathrm{kBq} / \mathrm{mL}$, the retardation in the cycle G2-M decreased obviously, but the retardation in the cycle $\mathrm{S}$ became obvious, reached the peak at $62.97 \%$ (Figure 3 ).

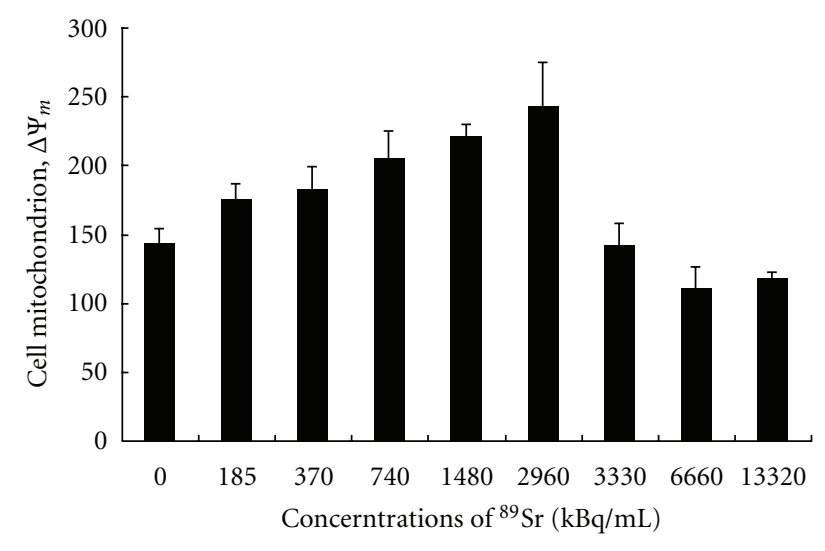

Figure 6: The mitochondrion $\Delta \Psi m$ of MCF-7 cell apoptosis due to being induced by ${ }^{89} \mathrm{Sr}$ of various radioactive concentrations.

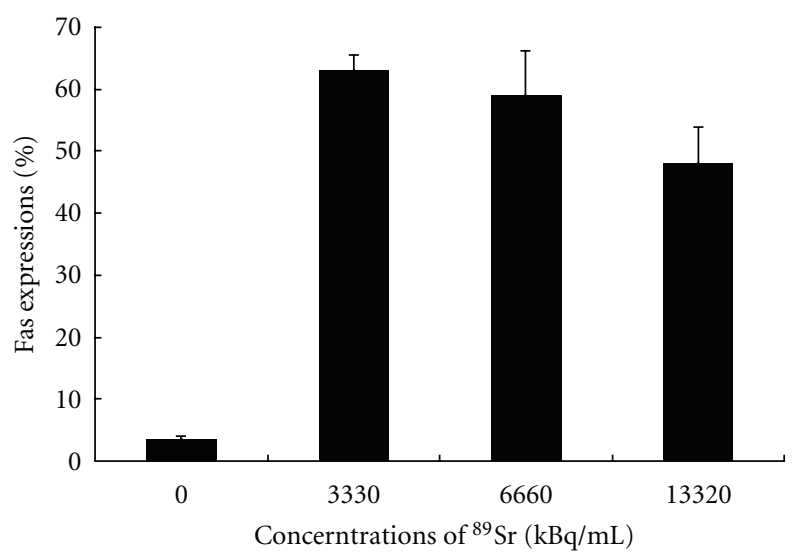

FIgUre 7: The Fas expression of MCF-7 cell due to being induced by ${ }^{89} \mathrm{Sr}$ of various concentrations.

3.4. MCF-7 Cell Apoptosis. Again after being induced by ${ }^{89} \mathrm{Sr}$ with the same radioactive concentrations and cultured for 24 hours, all the rates of cell apoptosis were lower than $10 \%$ (Figure 4 ). There were no obvious differences in all the groups $(P>.05)$. The DNA electrophoresis analysis in each group found no typical "ladder diagram" band distribution.

According to our previous study, the experimental group $3330 \mathrm{kBq} / \mathrm{mL}$ was divided into 4 groups: $36 \mathrm{~h}, 48 \mathrm{~h}, 72 \mathrm{~h}$, and $96 \mathrm{~h}$. With the time passing, the numbers of cell apoptosis increased obviously, reached the peak at $46.28 \%$ at $72 \mathrm{~h}$, and had a dosage-dependency relationship. However, most of cells died after 96 hours (Figure 5).

3.5. The Variation of MCF-7 Cell Mitochondrion $\Delta \Psi m$. After being induced by ${ }^{89} \mathrm{Sr}$ of radioactive concentrations and cultured for 24 hours, the cell mitochondrion $\Delta \Psi m$ did not decrease obviously but increased slightly when the concentration was lower than $3330 \mathrm{kBq} / \mathrm{mL}$. When the concentration was above $3330 \mathrm{kBq} / \mathrm{mL}$, the cell mitochondrion $\Delta \Psi m$ decreased obviously (Figure 6). 


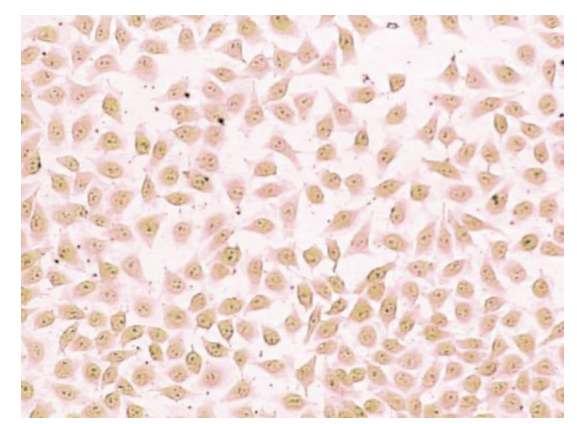

(a)

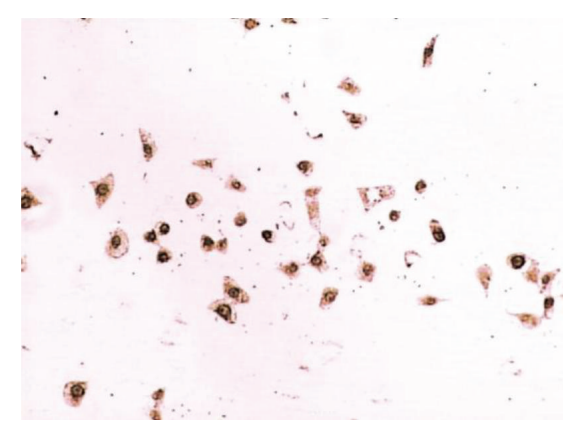

(c)

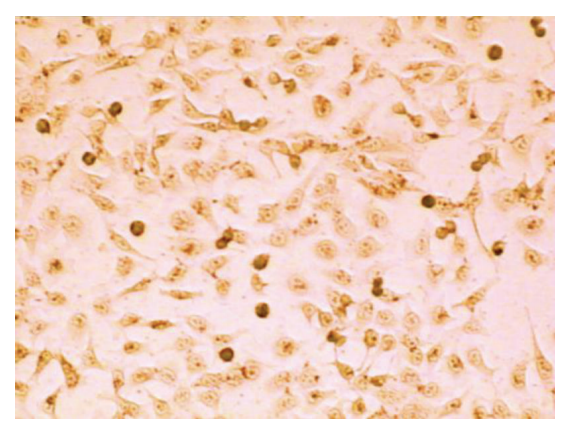

(b)

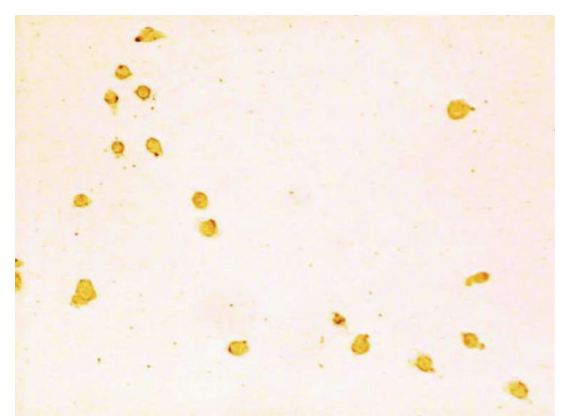

(d)

Figure 8: (a) P53 coloration before being induced; (b) bcl-2 coloration before being induced; (c) P53 coloration after being induced; (d) bcl-2 coloration after being induced.

3.6. The Fas Expression of MCF-7 Cell. Based on the pretest, induced MCF-7 cells in all the 3 experimental groups $(3330 \mathrm{kBq} / \mathrm{mL}, 6660 \mathrm{kBq} / \mathrm{mL}$, and $13320 \mathrm{kBq} / \mathrm{mL})$ for 24 hours, their Fas receptor expressions were obviously higher than their respective control groups (Figure 7).

3.7. Immunohistochemical Analysis. For the control group, the positive rate of P53 expression was 95\%, but the coloration generally weakened, weakly positive. While the positive rate of bcl-2 expression was $91 \%$, the coloration deepened.

For the experimental group $3330 \mathrm{kBq} / \mathrm{mL}$, after being induced for different periods, the positive rate of P53 expression was $97 \%$, but the coloration was obviously darker than the control group. While the positive rate of bcl2 expression was $88 \%$, the coloration generally weakened, especially in the group $72 \mathrm{~h}$ (Figure 8 ).

\section{Discussion}

${ }^{89} \mathrm{Sr}$ is a short-lived artificial radioisotope with a half-life of 50.5 days, which has very high energy ( $8 \mathrm{~mm}$ penetration). ${ }^{89} \mathrm{Sr}$ is used for the medical treatment of high metastatic bone tumor. Due to its simple treatment method and good curative effect, it has been found in widespread application $[5,6]$, but the unsatisfactory curative effect on some patients occurred due to their tumor cell resistance to the radiation. ${ }^{89} \mathrm{Sr}$ treatment mechanism primarily is to inhibit the growth of the tumor cells or to kill them by radiation damage. The previous studies on the radiation damage were mainly focused on the external radiation, especially X-ray or $\gamma$-ray, and few reports focus on the internal radiation of $\beta$-ray remitted by radionuclide. Because the internal radiation has the characteristics, selectivity of action spot and durability of acting time, it is very important to study the mechanism and contributing factors of the radiation damage by internal radiant of radionuclide.

The research findings showed that MCF-7 cells were induced by ${ }^{89} \mathrm{Sr}$ and irradiated by $\beta$-ray for 24 hours, the inhibition of cell proliferation was obvious, and had a positive correlation with the concentration of ${ }^{89} \mathrm{Sr}$. When the concentration reached $1480 \mathrm{kBq} / \mathrm{mL}$ and the cell absorbed dose reached $1 \mathrm{~Gy}$, the cell cycle retardation appeared obviously; this is mainly manifested in G2-M the cells in the cycle retardation time phase and other time phases had a proportional relation with the accumulative absorbed dose. In 1968, it is reported that the cell cycle G1 retardation was induced by X-ray. There were also many studies which reported that the tumor cell cycle retardation was induced by $\gamma$-ray radiation, and most of people thought that the tumor cell cycle G2-M retardation was induced by $\gamma$-ray radiation $[7,8]$. Such case was also found when MCF-7 tumor cells were induced by ${ }^{89} \mathrm{Sr}$ and irradiated by $\beta$-ray. In the experimental group $13320 \mathrm{kBq} / \mathrm{mL}$, the accumulative absorbed dose reached $9 \mathrm{~Gy}$, mass mortality of cell was found, and the cycle $\mathrm{S}$ retardation of the residual cells was obvious. 
The patterns of MCF-7 cell death induced by ${ }^{89} \mathrm{Sr}$ were apoptosis and necrosis, and they coexisted. When the radioactive concentration was lower than $2960 \mathrm{kBq} / \mathrm{mL}$ and the cell accumulative absorbed dose was less than $2 \mathrm{~Gy}$, although the inhibition of cell proliferation and cycle retardation were obvious, the cell apoptosis was not obvious and was independent of the time of irradiation. When the radioactive concentration reached $3330 \mathrm{kBq} / \mathrm{mL}$, after being cultured for 72 hours, the cell accumulative absorbed dose reached $6.76 \mathrm{~Gy}$, and the percentage of cell apoptosis increased obviously, reached the peak at $46.28 \%$, and had correlation with irradiation time. When the radioactive concentration reached $13320 \mathrm{kBq} / \mathrm{mL}$, the cell accumulative absorbed dose exceeded $9 \mathrm{~Gy}$, the percentage of cell necrosis increased obviously, and even total necrosis, and there were little apoptosis. That is because the cell apoptosis is an active process that needs gene expression and protein synthesis, when the radiation dose exceeds $9 \mathrm{~Gy}$ which is sufficient for destroying genetic transcription or directly destroying the integrality of membrane, it makes the cell unable to support the ion gradient inside and outside of cell, thus will make the loop of cell apoptosis unable to be initiated. When the accumulative absorbed dose falls in a certain range, both apoptosis and necrosis exist, and the ratio of necrosis to apoptosis is related to irradiation time and dose effect. The apoptosis rate as the function of the dose of ${ }^{89} \mathrm{Sr}$ was not significant, that is because the apoptosis rate is related to irradiation time, dose, and some other factors. For the accumulative absorbed dose $4.5 \mathrm{~Gy}$, apoptosis was few when the cell was induced by the radioactive concentration at $6660 \mathrm{kBq} / \mathrm{mL}$ for 24 hours, while apoptosis increased obviously when the cell was induced by the radioactive concentration at $3330 \mathrm{kBq} / \mathrm{mL}$ for 48 hours. It is explained that if the cell absorbed the same dose in a short or long period, the pattern of cell death is different. It is because DNA damage caused by high dose once in a short period was more serious than that caused by low dose for many times; the cell was unable to heal caused by high dose once. The above manifestation, basically, is the same as the changes of cells irradiated externally. But some research findings showed that, if the same dose was adopted, the proportion of cell apoptosis induced by $\gamma$-ray is higher than that induced by $\beta$-ray; similarly, the loop was initiated earlier [4].

The radiation-induced inhibition of proliferation did not appear to be related to apoptosis, but rather to delayed progression through the cell cycle [6].

In the process of MCF-7 cell apoptosis induced by ${ }^{89} \mathrm{Sr}$, there are many genes involved in regulation and expression. Among them, gene P53 and bcl-2 play an active role. The gene P53, as a transcription, combines and involves in genetic regulation, plays an important role in the cell apoptosis induced by the radiation or other factors [9-11]. The gene bcl-2 can inhibit the cell apoptosis induced by many factors, including ionizing radiation, over oxidation of plasma membrane, and lack of blood serum and growth factor [12-14]. In the experimental group with obvious apoptosis in this research, the coloration of cell karyon deepened obviously, p53 expression was reinforced, and the coloration of cell cytoplasm weakened obviously, bcl-2 expression was depressed. It shows that the cell apoptosis induced by $\beta$-ray radiation was initiated by the high expression of p53 and is depressed by bcl-2 expression.

In the process of MCF-7 cell apoptosis induced by ${ }^{89} \mathrm{Sr}$, Fas and plastosome are also involved in regulation and expression. It is proved that Fas plays an important role in the process of cell apoptosis induced by radiation damage and other DNA damage [15-17]. In the experimental group with obvious apoptosis in this research, Fas expression is higher than that of the control group. It shows that Fas expression is also involved in the signal transmission of apoptosis in the process of cell apoptosis induced by $\beta$-ray radiation. There are probably two ways of Fas expression mediates the signal transmission of the next level: through the actions of cystic death domain (DD) and cystic connector proteins, Fas initiates the caspase- 8 and leads to the cell apoptosis; Fas plays a role in inducing the cell apoptosis through the ceramide, as second messenger [18]. Similarly, in the experimental group with obvious apoptosis, the plastosome $\Delta \Psi m$ decreased obviously, comparing with any other group, which shows that the plastosome is also involved in the cell apoptosis induced by $\beta$-ray radiation. The probable mechanism is that the plastosome initiates the caspases through releasing Cyt c, plays an important controlling role [19]. In some other cancer cells, apoptosis induced by ${ }^{89} \mathrm{Sr}$ is regulated by decreasing the bcl-2 expression protein, thus decreasing bcl-2/bax [20].

In short, after being irradiated by $\beta$-rays, the inhibition of MCF-7 cell proliferation and its rate in various periods are changing with the amount of radiation dose. If the accumulative absorbed dose falls in a certain range, $\beta$-ray can induce the cell apoptosis and also the cell necrosis, and there is a dose-effect curve. Many genes are involved in regulation and expression in the process of cell apoptosis, and the signal transmission and regulation are very intricate. It is very important to the tumor radiotherapy in the further research.

\section{References}

[1] A. Jemal, R. Siegel, E. Ward, T. Murray, J. Xu, and M. J. Thun, "Cancer statistics, 2007," Ca-A Cancer Journal for Clinicians, vol. 57, no. 1, pp. 43-66, 2007.

[2] M. Bralic, M. Muhvic-Urek, V. Stemberga et al., "Cell death and cell proliferation in mouse submandibular gland during early post-irradiation phase," Acta Medica Okayama, vol. 59, no. 4, pp. 153-159, 2005.

[3] C. Fournier and G. Taucher-Scholz, "Radiation induced cell cycle arrest: an overview of specific effects following highLET exposure," Radiotherapy and Oncology, vol. 73, no. 2, pp. S119-S122, 2004.

[4] C. Friesen, A. Lubatschofski, J. Kotzerke, I. Buchmann, S. N. Reske, and K. M. Debatin, "Beta-irradiation used for systemic radioimmunotherapy induces apoptosis and activates apoptosis pathways in leukaemia cells," European Journal of Nuclear Medicine and Molecular Imaging, vol. 30, no. 9, pp. 1251-1261, 2003.

[5] J. Milner, "DNA damage, p53 and anticancer therapies," Nature Medicine, vol. 1, no. 9, pp. 879-880, 1995.

[6] N. A. Scott, I. R. Crocker, Q. Yin, D. Sorescu, J. N. Wilcox, and K. K. Griendling, "Inhibition of vascular cell growth 
by X-ray irradiation: comparison with gamma radiation and mechanism of action," International Journal of Radiation Oncology Biology Physics, vol. 50, no. 2, pp. 485-493, 2001.

[7] A. Sak, R. Wurm, B. Elo et al., "Increased radiation-induced apoptosis and altered cell cycle progression of human lung cancer cell lines by antisense oligodeoxynucleotides targeting p53 and p21 WAF1/CIP1," Cancer Gene Therapy, vol. 10, no. 12, pp. 926-934, 2003.

[8] T. Suda, T. Takahashi, P. Golstein, and S. Nagata, "Molecular cloning and expression of the Fas ligand, a novel member of the tumor necrosis factor family," Cell, vol. 75, no. 6, pp. 11691178, 1993.

[9] K. Y. Jen and V. G. Cheung, "Identification of novel p53 target genes in ionizing radiation response," Cancer Research, vol. 65, no. 17, pp. 7666-7673, 2005.

[10] B. Fischer, S. Benzina, P. Jeannequin et al., "Fast neutronsinduced apoptosis is Fas-independent in lymphoblastoid cells," Biochemical and Biophysical Research Communications, vol. 334, no. 2, pp. 533-542, 2005.

[11] K. Viktorsson, L. De Petris, and R. Lewensohn, "The role of p53 in treatment responses of lung cancer," Biochemical and Biophysical Research Communications, vol. 331, no. 3, pp. 868880, 2005.

[12] T. Hara, M. Omura-Minamisawa, C. Chao, Y. Nakagami, M. Ito, and T. Inoue, "Bcl-2 inhibitors potentiate the cytotoxic effects of radiation in Bcl-2 overexpressing radioresistant tumor cells," International Journal of Radiation Oncology Biology Physics, vol. 61, no. 2, pp. 517-528, 2005.

[13] J. Wendt, C. von Haefen, P. Hemmati, C. Belka, B. Dörken, and P. T. Daniel, "TRAIL sensitizes for ionizing irradiationinduced apoptosis through an entirely Bax-dependent mitochondrial cell death pathway," Oncogene, vol. 24, no. 25, pp. 4052-4064, 2005.

[14] I. M. Ghobrial, T. E. Witzig, and A. A. Adjei, "Targeting apoptosis pathways in cancer therapy," Ca-A Cancer Journal for Clinicians, vol. 55, no. 3, pp. 178-194, 2005.

[15] T. Hamasu, O. Inanami, T. Asanuma, and M. Kuwabara, "Enhanced induction of apoptosis by combined treatment of human carcinoma cells with $\mathrm{X}$ rays and death receptor agonists," Journal of Radiation Research, vol. 46, no. 1, pp. 103110, 2005.

[16] M. E. Szperka, E. E. Connor, M. J. Paape, J. L. Williams, and D. D. Bannerman, "Characterization of bovine FAS-associated death domain gene," Animal Genetics, vol. 36, no. 1, pp. 63-66, 2005.

[17] A. Semont, E. B. Nowak, C. Silva Lages et al., "Involvement of p53 and Fas/CD95 in murine neural progenitor cell response to ionizing irradiation," Oncogene, vol. 23, no. 52, pp. 8497$8508,2004$.

[18] S. J. Chmura, E. Nodzenski, M. A. Beckett, D. W. Kufe, J. Quintans, and R. R. Weichselbaum, "Loss of ceramide production confers resistance to radiation-induced apoptosis," Cancer Research, vol. 57, no. 7, pp. 1270-1275, 1997.

[19] K. Cain, S. B. Bratton, C. Langlais et al., "Apaf-1 oligomerizes into biologically active $\sim 700-\mathrm{kDa}$ and inactive $\sim 1.4-\mathrm{MDa}$ apoptosome complexes," The Journal of Biological Chemistry, vol. 275, no. 9, pp. 6067-6070, 2000.

[20] J. Zhang, C. Hong, and S. Zhu, "The characteristics and mechanism of apoptosis in K562 cells induced by radionuclides strontium-89," Journal of Radiation Research and Radiation Progressing, vol. 21, no. 1, pp. 416-418, 2003. 


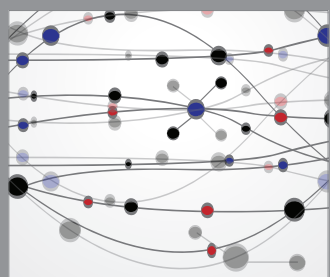

The Scientific World Journal
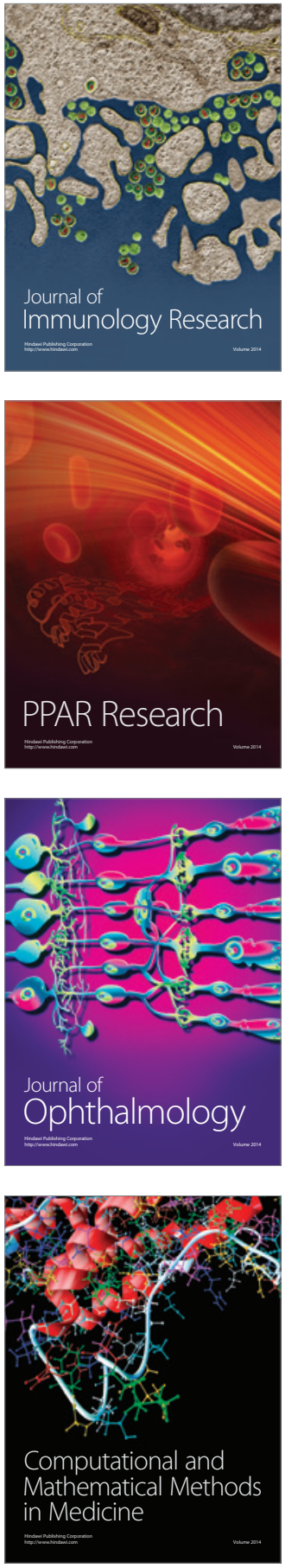

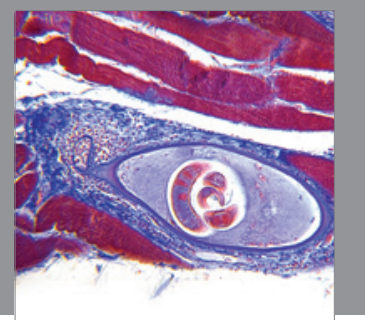

Gastroenterology

Research and Practice
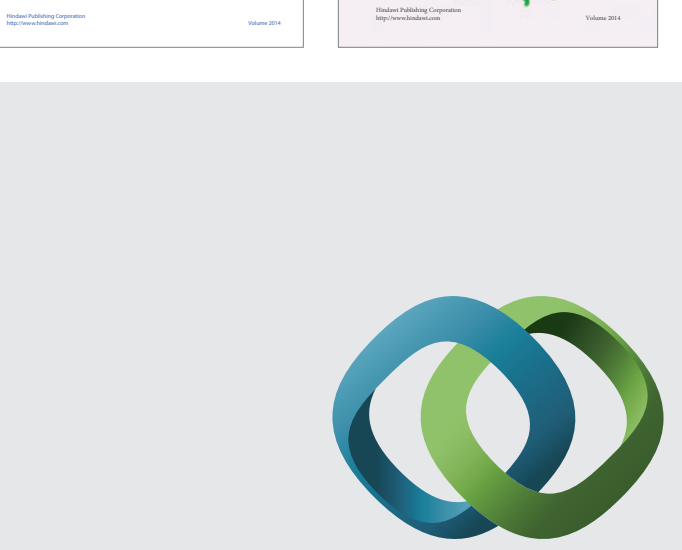

\section{Hindawi}

Submit your manuscripts at

http://www.hindawi.com
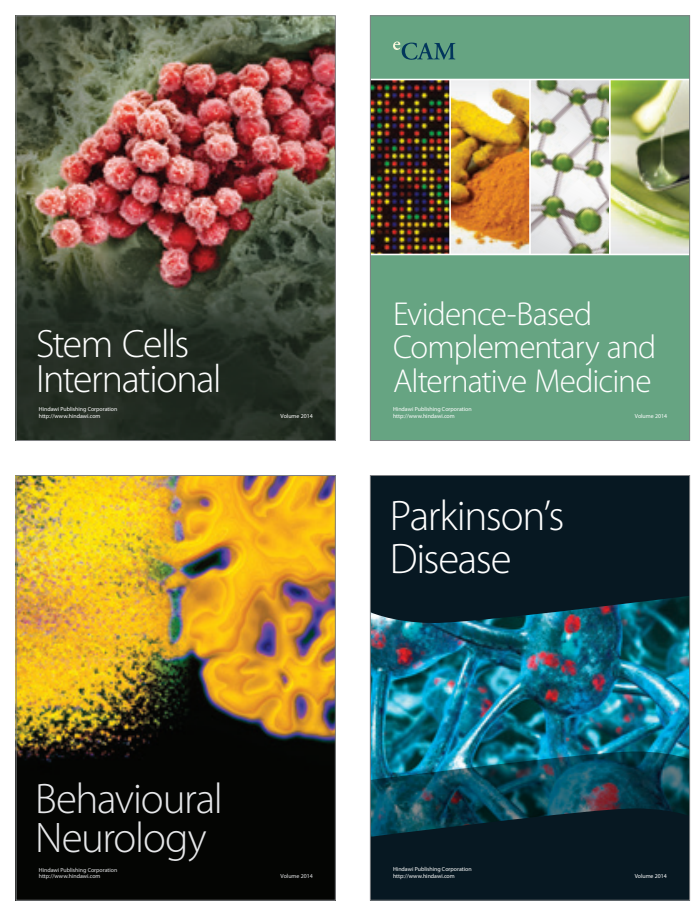

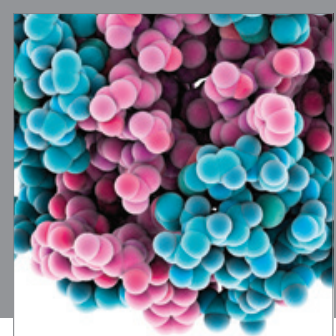

Journal of
Diabetes Research

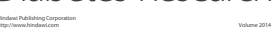

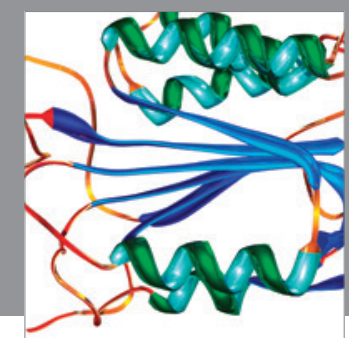

Disease Markers
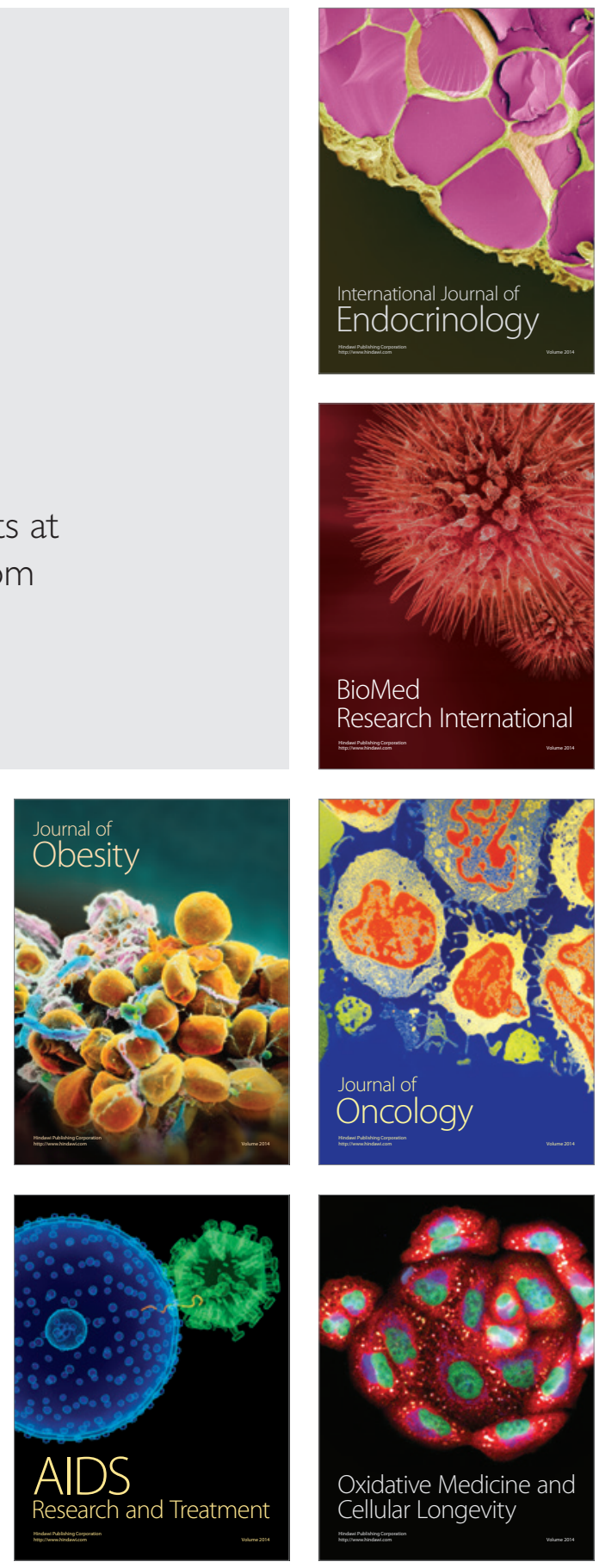